\title{
In Memory of Tracy Goodall
}

\author{
W. Kim Halford and Jan Lawton. \\ University of Queensland
}

It is our sad duty to report to the readers of Behaviour Change that Ms Tracy Goodall, a well known ABMA member and former president of the Queensland Branch, was killed in a motor vehicle accident on Friday March 5, 1993.

We had the pleasure of knowing and working with Tracy for many years, and want briefly to recount some markers of her all-too-brief life.

Tracy was born 34 years ago at Yallourn Hospital in the Latrobe Valley of eastern Victoria. This valley was dominated by the Victorian State Electricity Commission, and was a poor and under-serviced area. When she was 9 years old her teacher told the class that boys needed to think of getting a trade, and girls needed to think of getting a man who had a trade. Even at that young age, Tracy thought little of that advice, and sought to make her own path in life.

After completing secondary school in Hervey Bay, Queensland, Tracy decided to pursue university studies. Although none of her family had ever undertaken university studies, both her parents were very supportive of this decision. Their support, and later the support of her husband Mark, provided Tracy with a solid foundation of strength for the years ahead.

Tracy enrolled initially in Environmental Sciences at Griffith University, but soon realised that her interests lay more in the helping professions. She trained and worked for some time as a nurse, before completing first her Bachelors, then Honours Degrees in Psychology at James Cook University. Tracy's exceptional talents were becoming obvious at this time, and she was awarded the Australian Psychological Society prize for being the outstanding Honours Student at her Department.

In 1986 Tracy joined the staff of the University of Queensland Psychiatry Department as a specialist tutor in psychology. Here she combined nursing skills, psychology training, and great personal warmth to make an out- standing contribution to teaching in the Department. However, she still craved further challenges and enrolled in a $\mathrm{PhD}$ within the Department. She applied for and was awarded the Menzies Allied Health Doctoral Research Fellowship in 1988, and worked two years full time on her research. She was also awarded a major research grant by the Australian Health Department, established collaborative research projects with the Royal Brisbane and Princess Alexandra Hospitals, and commenced publishing her work in international journals.

It was during this time that Tracy started her association with the Queensland Branch of the ABMA. She assisted the Overseas Visitor's Committee, was Treasurer for the Branch Executive Committee, and was Queensland State President for 1990 and 1991. She also established a reputation for research excellence with regular paper presentations at the ABMA's national conferences, as well as contributing substantially to conference social life.

In 1991 Tracy moved to the Faculty of Nursing and Health Sciences at Griffith University's Gold Coast campus as a lecturer in Behavioural Sciences. That year she completed data collection for her thesis and in 1992 was promoted to Senior Lecturer in Nursing. In 1992 she provided leadership in the establishment of honours and postgraduate research courses at Griffith and wrote up her PhD. Throughout 1991 and 1992 Tracy played a key role in the organisation of the fourth World Congress on Behaviour Therapy. Her position as Social Events Coordinator for the Congress, was regarded as highly appropriate, given her love of fine food, fine wine and a good party.

In 1993 Tracy was selected for the positions of Deputy Dean Academic for her faculty and Chair of the University's Affirmative Action Committee. The rights of women to pursue academic careers on an equal footing with men, has long been an issue dear to her heart.

In a very short space of time, Tracy had risen 
to national prominence as a teacher, researcher, and professional innovator. All this had been accomplished whilst completing her own PhD. She planned to present her research at a major conference in the USA later this year, and it seems likely she would have rapidly attained an international reputation for her work.

After documenting all that Tracy did, and seemed destined to do, the reader might think that this tells the story of Tracy Goodall. But her teaching, research and clinical work is not the reason those of us who knew her well, rejoiced in her. Her ultimate worth was in the person that she was. We know of dozens of people who turned to Tracy for support, and encouragement in hard times. We all have memories of personal crises she helped us to work through. Despite her tremendous work rate Tracy made time to offer of herself. She also provided a role model for others, showing us how much it was possible to achieve.

Tracy was someone who savoured life. She lived her life the way she wanted. She enjoyed every minute. She had been known to pause at the sight of natural beauty and to shout "isn't life just wonderful!".

We will miss Tracy Goodall. She enriched both our lives, and the lives of others who knew her. Her example of overcoming barriers, persisting, and rejoicing in her own and other's successes is a lesson for us all. On behalf of the Association we extend our sympathy to her husband Mark, mother Margaret, father Brian, brother Glen, and all her many friends and colleagues. 